\title{
https://doi.org/10.46813/2021-134-122 \\ SIMULATION OF THE COMPENSATION OF A HIGH-CURRENT ION BEAM BY AN ELECTRON BEAM IN A CUSP MAGNETIC SYSTEM
}

\author{
I.N. Onishchenko, O.V. Fedorovskaya \\ National Science Center "Kharkov Institute of Physics and Technology”, Kharkiv, Ukraine \\ E-mail: onish@kipt.kharkov.ua
}

The results of 2.5D-simulation of the dynamics of particles of a high-current ion beam moving in a magnetic field of acute-angled geometry (cusp), compensated in charge and current by an electron beam injected along the radius onto the axis from the periphery, uniformly in azimuth, are presented. The influence of own space charge fields and polarization fields on the dynamics of ions is clarified. It is shown that at high densities of the electron and ion beams, the electron beam injected into the cusp together with the ion beam, moving along the magnetic field lines, drags the ion beam away from the axis to the periphery into the region of zero magnetic field. At the exit from the cusp, the electron beam injected along the radius onto the axis drifts along the axis in a uniform magnetic field, while the ion beam performs oscillatory motion by radius in the crossed the electric field of the electron beam space charge and the longitudinal magnetic field.

PACS: 41.75.-i, 52.40.Mj, 52.58.Hm, 52.59.-f, 52.65.Rr

\section{INTRODUCTION}

High-current ion beams are in demand in the problem of controlled thermonuclear fusion with magnetic confinement for their injection into magnetic traps, in particular, acute-angled geometry [ $1-4]$, which ensures the hydrodynamic stability of the confined plasma; inertial thermonuclear fusion on heavy ion beams of an induction accelerator [5]; increasing the productivity of separation and disposal of radioactive waste $[6,7]$, etc.

The dynamics of ions in the above concepts was mainly considered in the one-particle approximation, while at high densities of ion beams, an essential role is played by the electric fields of the space charge and the magnetic fields of the ion beams current. HIBs compensation with electrons [8] or electron beams [5], as well as the use of a plasma flow instead of a high-current ion beam [9] gives hope to avoid the undesirable influence of the intrinsic fields of high-current ion beams.

In the present work, in the approximation of axial symmetry using the 3D code "KARAT" [10], we study the $2.5 \mathrm{D}$ dynamics of an ion beam with charge and current compensation by an electron beam (i.e., plasma flow) and without its compensation at injection into the first half of the cusp, depending on the density of the beams. The possibility of compensation an ion beam moving along the axis at the exit from the cusp in a uniform magnetic field, by radially converging to the axis with an additional circular electron beam uniform in azimuth, injected from the region of zero magnetic field of the cusp, has been considered.

The parameters of the electron beam and the topography of the cusp magnetic field are chosen in such a way that when it meets the ion beam, they have the same densities, axial velocities, and transverse dimensions. The positions of the ion and compensating electron beams on the $(\mathrm{r}, \mathrm{z})$-plane in the steady state with stationary beam injection are given.

\section{FORMULATION OF THE PROBLEM}

The magnetic field is created by two coils with opposite currents (the so-called "cusp" [1 - 3]) and a solenoid (region of uniform magnetic field $B_{0}=3.4 \mathrm{~T}$ ), fol- lowed by another cusp in the case of an induction accelerator [5]. The system length: $z_{\mathrm{L}}=50 \mathrm{~cm}$, radius: $r_{\mathrm{L}}=7 \mathrm{~cm}$. On the left, tubular ion (energy $W_{i}=240 \mathrm{keV}$ ) and main electron beams of the same velocity $\left(v_{\mathrm{i}}=v_{\mathrm{e}}\right)$ and density $\left(n_{\mathrm{i}}=n_{\mathrm{e}}\right)$ are injected, i.e. $I_{i}=I_{e}$, with external and internal radii $r_{\text {min }}=0.7 \mathrm{~cm}, r_{\text {min }}=1.4 \mathrm{~cm}$ (Fig. 1). From the periphery of the second part of the cusp, radial injection of the additional circular electron beam with an energy of $W^{\text {add }}=2.5 \mathrm{MeV}$ onto the axis is carried out. The density of particles in the ion beam was chosen equal to $n_{\mathrm{i}}=10^{10} \ldots 10^{12} \mathrm{~cm}^{-3}$, obtained in the experiment [11].

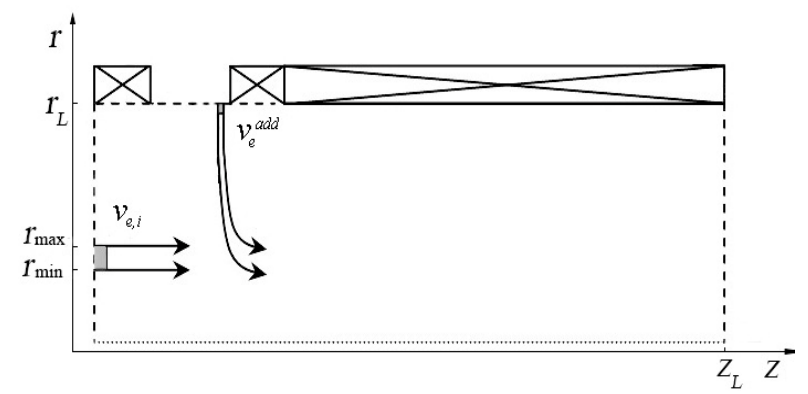

Fig. 1. Geometry of the magnetic system and injection regions of the ion and two electron beams

\section{INJECTION OF IONS IN THE CASP. SINGLE-PARTICLE APPROXIMATION}

To reveal the differences between the results of the dynamics of high-current ion beams injected into the cusp magnetic field and the results of this dynamic in a single-particle approximation, we present for comparison the results have been obtained in $[1,2]$ on the injection of single ions into the cusp through its entrance along the axis. It is shown that, depending on the injection radius, the injected ions are divided into three groups. For the injection radius $0 \leq r \leq 0.71 \rho_{L}$, where $\rho_{L}=M v_{0} / e B_{0}$, ions with velocity $v_{0}$ pass through the cusp (Fig. 2). At that on left of zero magnetic field plane, the ion moves along the axis, slightly rotating in $\varphi$, without encircling the axis, and on right, rotation begins with encircling the axis. The closer the injection radius is to $0.71 \rho_{L}$, the greater part of the ion energy is 
converted into transverse energy and the denser spiral formed by the ion in the right half of the cusp.

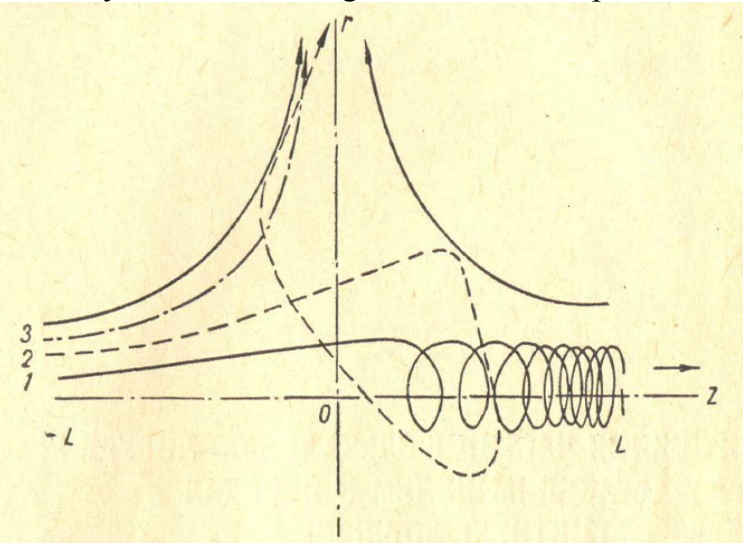

Fig. 2. Three types of ion trajectories depending on the radius of injection into the cusp [3]:

$$
\begin{gathered}
1-0 \leq r \leq 0.71 \rho_{L} ; 2-0.71 \rho_{L}<r<\sqrt{r_{L} \rho_{L}} ; \\
3-r \geq \sqrt{r_{L} \rho_{L}}
\end{gathered}
$$

Ions with an injection radius $0.71 \rho_{L}<r<\sqrt{r_{L} \rho_{L}}$, where $r_{\mathrm{L}}$ is the radius of the circular slit of the cusp, having made several reflections from the magnetic walls of the cusp, leave it through the entrance or circular slit. Ions with an injection radius $r \geq \sqrt{r_{L} \rho_{L}}$ leave the cusp without crossing the plane of the zero magnetic field.

In this article, for the taken parameters of simulation $\rho_{L}=2.08 \mathrm{~cm}, r_{\text {min }}, r_{\max }<0.71 \rho_{L}$ the case of the first group ions injection is being considered. So obtained results will be compared with this case.

\section{INJECTION OF A HIGH-CURRENT UNCOMPENSED ION BEAM INTO A CASP}

The main difference between a high-current ion beam is caused by the electric field of its space charge, which leads to radial repulsion of ions and the beam radius increasing. As a result, the injected ions gradually pass from the first group of ions propagating along the cusp region to the second and third groups of ions reflected from the magnetic wall of the cusp and leaving into the annular slit. This is demonstrated by the picture of the ion beam particles position on the (r, z)-plane in Fig. $3, \mathrm{a}, \mathrm{b}$ at the time $\mathrm{t}=150 \mathrm{~ns}$.

From Fig. 3,a,b, it can be seen that a significant part of the ions is reflected back to the entrance to the cusp or goes into the annular slit of the cusp, and only a small part of them overcomes the cusp magnetic field and is subsequently transported in a uniform magnetic field with transverse dimensions several times larger than the input ones. For an ion beam of higher density (iyy Fig. $3, \mathrm{~b})$, the described dynamics is aggravated by a more distinct repulsion of ions, so that the number of ions that have passed through the cusp decreases. The obtained distribution of the high-current ion beam particles is radically different from that in a single-particle analysis. According to it, all particles of the ion beam with the parameters we have chosen pass the cusp and propagate in the region of a uniform magnetic field, rotating along spiral trajectories that encompass the axis (iyy Fig. 2).
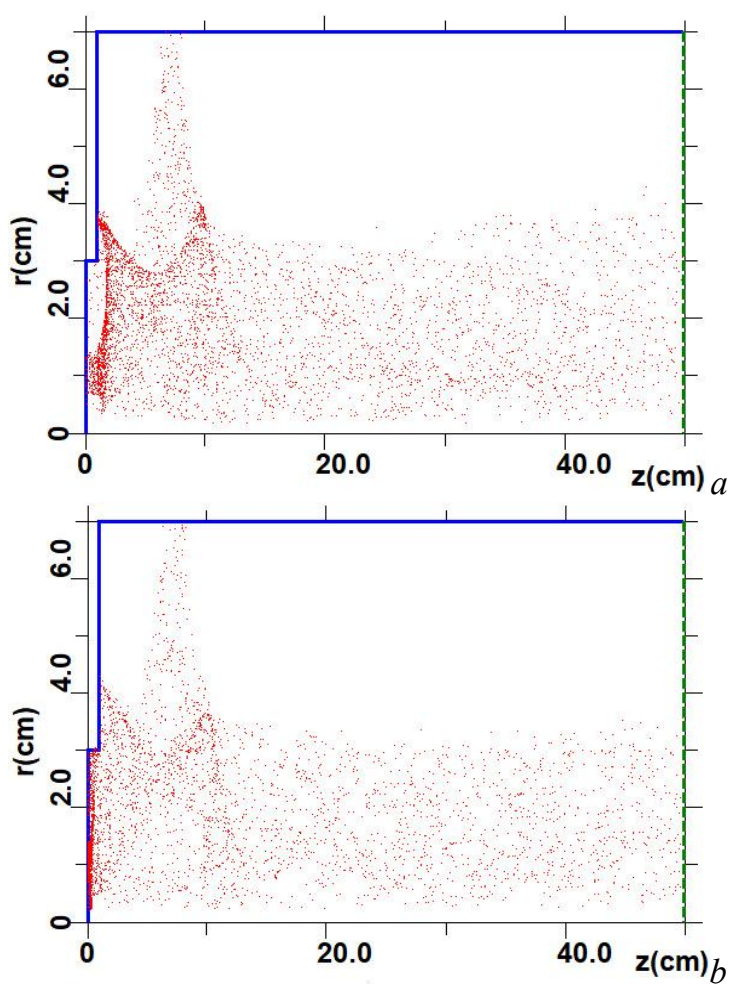

Fig. 3. Ion beam particle arrangement on $(r, z)$-plane:

$$
\begin{aligned}
& n_{i}=10^{11} \mathrm{~cm}^{-3} ; W_{i}=240 \mathrm{keV}(\mathrm{a}) ; \\
& n_{i}=10^{11} \mathrm{~cm}^{-3} ; W_{i}=240 \mathrm{keV}(\mathrm{b})
\end{aligned}
$$

\section{INJECTION OF A HIGH-CURRENT COMPENSATED ION BEAM INTO CASP}

Let us consider the dynamics of particles of a highcurrent ion beam, compensated in charge and current by an electron beam having the same velocity and density as the ion beam. This situation is equivalent to the injection of a plasma flow of the corresponding density and velocity into a magnetic trap of the cusp type $[1,2]$.

Numerical modeling has been carried out for the densities of the ion and main electron beams $n_{i}=n_{e}$ $=10^{10} ; 10^{11}$, и $10^{12} \mathrm{~cm}^{-3}$, respectively, of currents $J_{i}=J_{e}$ $=5 ; 50$, and $500 \mathrm{~A}$ at their energies and transverse dimensions indicated above.

For the lower of the selected densities, the arrangement of the particles of the ion and main electron beams on the rz-plane is shown in Fig. 4,a. It illustrates, that the compensation allows avoiding the radial repulsion of the ion beam until the electrons and ions disperse in space - electrons with a small Larmor radius will escape along the magnetic field lines of the cusp, and ions, being at the selected parameters, particles of the first type (see Section 2) will pass from the cusp into a uniform magnetic field. The ions, being uncompensated, acquire a radial velocity both in the intrinsic space charge field and in the polarization field of the separated electron and ion beams. The latter is enhanced in the region of rotation of the electron beam from the axial direction to the radial direction. Therewithal due to the rearrangement of the directed velocity of the electrons into the rotational one, the linear density of the electron beam and the electric field of its space charge increase. This leads to the Larmor rotation of ions in the region of a uniform magnetic field. The difference in their trajectories, caused by different injection radii at the entrance, 
explains the obtained characteristic picture of different amplitudes of ion oscillations on the $(r, z)$-plane in the region of a uniform magnetic field (see Fig. 4,a).

Note that, in contrast to the single-particle consideration (see Fig. 2), in the high-current case, the ions rotate practically outside the tubular space of the injected beam, without covering the cusp axis.

The arrangement of the particles of the ionic and main electron beams on the (r, z)-plane for an average density $n_{i}=n_{e}=10^{11} \mathrm{~cm}^{-3}$ is shown in Fig. 4,b. In this case, the electric fields of the both beams space charge increased so much that the magnetized electron beam drags along the main part of the ion beam into the annular slit of the cusp. The rest of the beam ions passes into the region of a uniform magnetic field, chaotically mixing their rotational trajectories.

The arrangement of the particles of the ion and main electron beams on the (r, z)-plane for a high density $n_{i}=n_{e}=10^{12} \mathrm{~cm}^{-3}$ is shown in Fig. 4,c. It can be seen that almost entire ion beam is carried away by the electron beam and performs several oscillations relative to the electron beam. Less than $1 \%$ of the particles of the ion beam pass into the region of a uniform magnetic field.
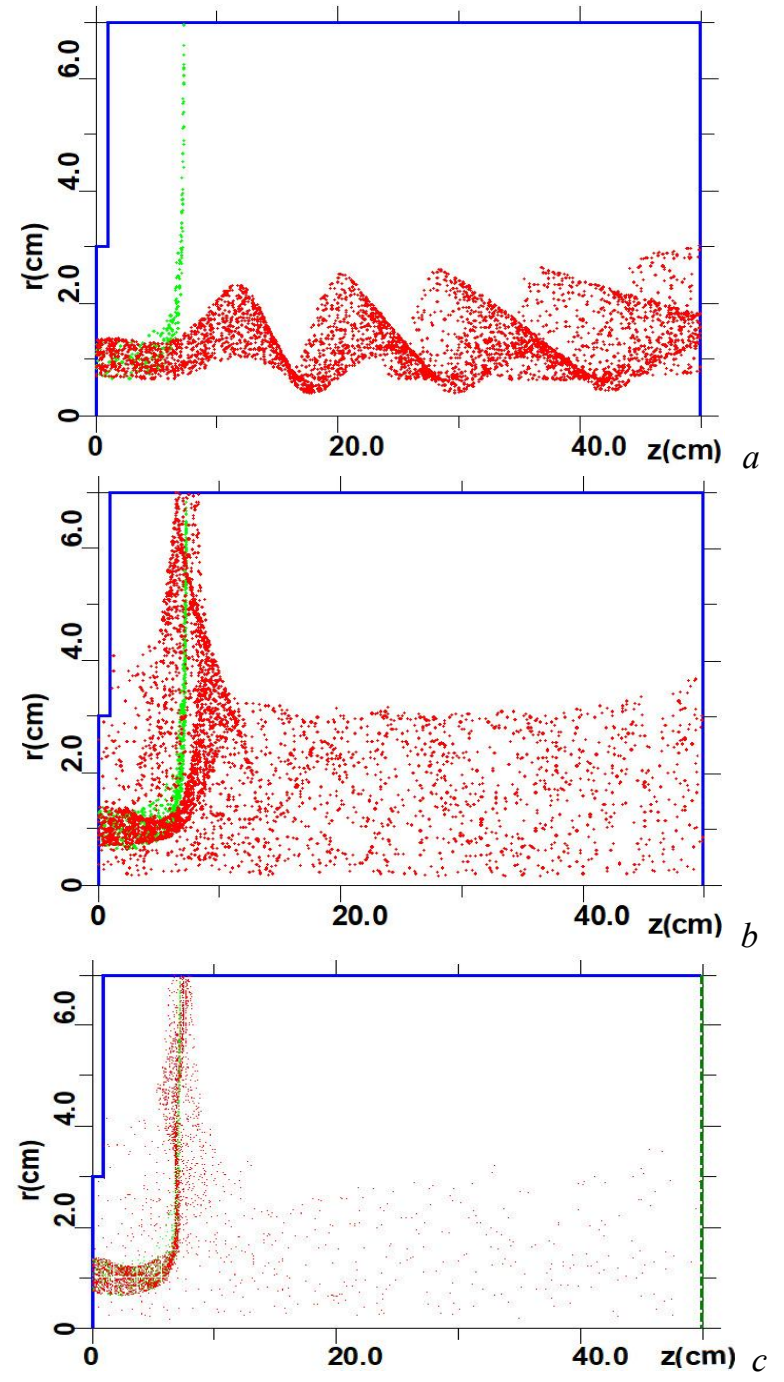

Fig. 4. Arrangement of particles of ion (red) and main electron (green) beams on the $(r, z)$-plane: $n_{i}=n_{e}=10^{10} \mathrm{~cm}^{-3}, W_{i}=240 \mathrm{keV}(\mathrm{a}) ;$
$n_{i}=n_{e}=10^{11} \mathrm{~cm}^{-3}, W_{i}=240 \mathrm{keV}(\mathrm{b}) ;$
$n_{i}=n_{e}=10^{12} \mathrm{~cm}^{-3}, W_{i}=240 \mathrm{keV}(\mathrm{c})$
The results of this section are important for solving the problem of separation of multicomponent plasma injected into a curvilinear magnetic field. A theoretical consideration of the problem [12] shows the preservation of the direction of the injected plasma flow in a curvilinear magnetic field for an infinite case. Under real experimental conditions $\left(90^{\circ}\right.$ toroidal pipe section with a magnetic field [13], axial systems of finite transverse dimensions [1 - 9], etc.) for high density plasma flows, due to the appearance of significant polarization fields a plasma flow moves along magnetic force lines.

\section{INJECTION OF AN ELECTRON BEAM INTO THE ANNULAR SLIT OF THE CUSP}

Let us consider the possibility of a high-current ion beam compensation using the magnetic field of the cusp. For this purpose, an additional electron beam is injected into the cusp annular slit uniformly along the entire azimuth, and propagating along the magnetic field lines of the cusp, fills the tubular region in a uniform magnetic field, along which the ion beam propagation is assumed, i.e. in order to carry out their coincidence in space. In this case, it is necessary to choose the injected electron beam parameters in such a way to ensure its density and longitudinal velocity in the region of a uniform magnetic field, equal to the density and velocity of the ion beam. This would make it possible to realize the charge and current compensation of the ion beam.

In the numerical simulation in the case of the ion beam high density $\left(n_{i}=10^{12} \mathrm{~cm}^{-3}\right)$, following parameters of the additional electron beam have been selected: $n_{e}{ }^{\text {add }}=10^{12} \mathrm{~cm}^{-3} ; W^{\text {add }}=2.5 \mathrm{MeV}$.

Fig. 5 shows the obtained location of particles of additional electron beam on the $(r, z)$-plane in the steady state.

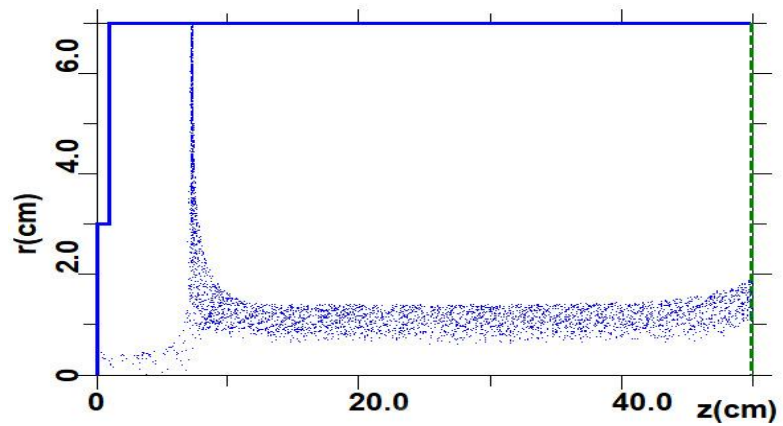

Fig. 5. Arrangement of additional electron beam

$$
\begin{gathered}
\text { particles on the }(r, z) \text {-plane: } \\
n_{e}^{\text {add }}=10^{12} \mathrm{~cm}^{-3}, W^{\text {add }}=2.5 \mathrm{MeV}
\end{gathered}
$$

In the area of a uniform magnetic field, it can be seen the formation of a tubular electron beam aimed to compensate the high-current ion beam. When the electron beam turns from the radial direction of motion to a slower longitudinal direction, the resultant increased negative space charge pushes a small part of the beam electrons into the region of zero magnetic field of the cusp.

\section{COMPENSATION OF ION BEAM IN CUSP BY AN ANNULAR ELECTRON BEAM}

The numerical modeling shows that for the ion beam low density $\left(n_{i}=10^{10} \mathrm{~cm}^{-3}\right)$, it turned out to be combined with an additional electron beam in the region of a uni- 
form magnetic field (Fig. 6,a). However, when it encounters the electron beam, the ion beam is accelerated by the space charge field of the electron beam, acquiring also a radial velocity. In the uniform magnetic field, the ion beam particles perform radially oscillatory motion in the crossed radial electric field of the electron beam space charge and the longitudinal magnetic field.

The ion beam with density of $n_{i}=10^{11} \mathrm{~cm}^{-3}$, even before it meets the electron beam, acquires a significant radial spread in its intrinsic electric field (Fig. 6,b), which leads to oscillations of a much larger amplitude in the region of the uniform magnetic field.
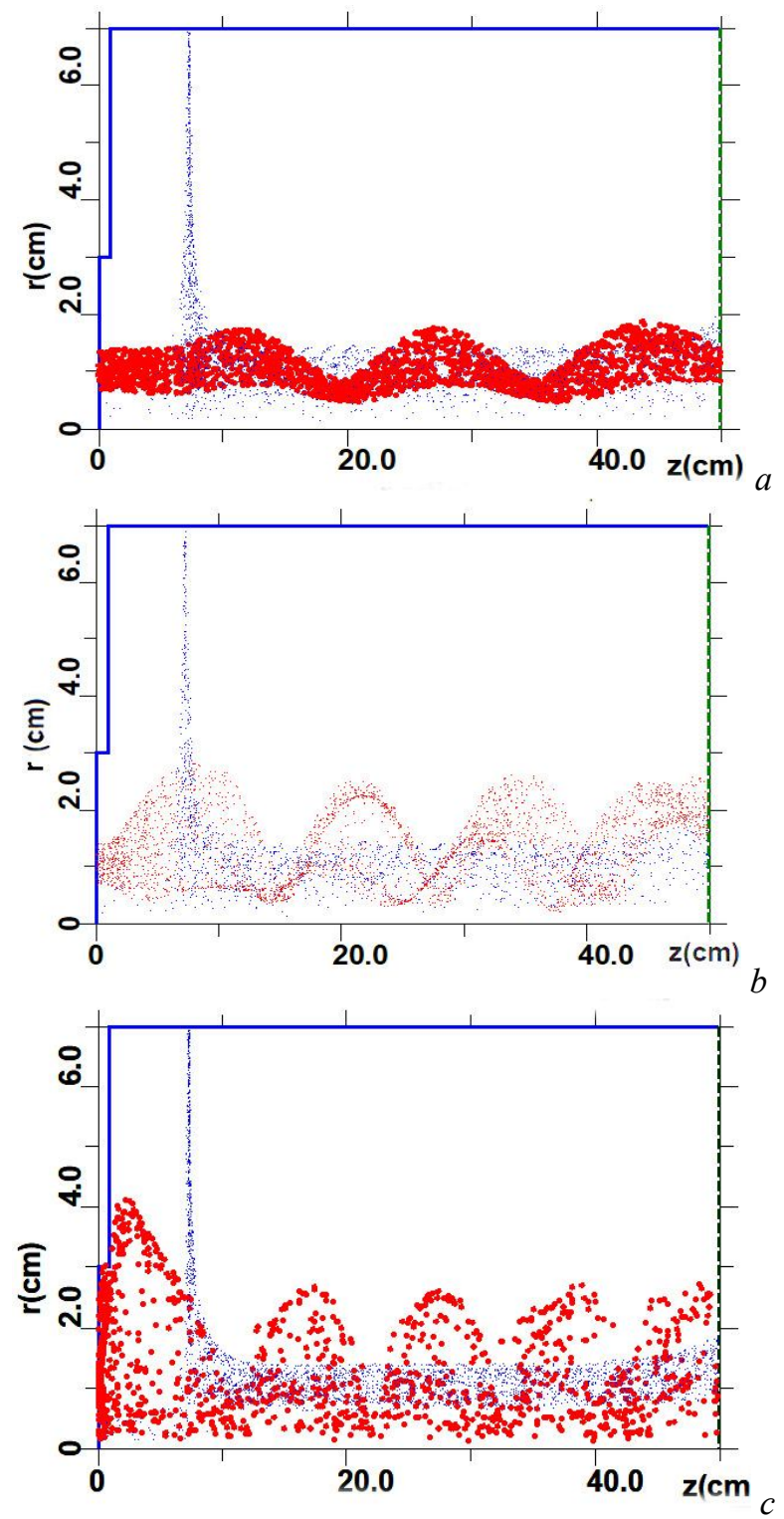

Fig. 6. Arrangement of particles of the ion (red) and additional electron (blue) beams on the $(r, z)$-plane: $n_{i}=n_{e}^{a d d}=10^{10} \mathrm{~cm}^{-3}, W_{i}=240 \mathrm{keV}, W^{a d d}=2.5 \mathrm{MeV}(a)$; $n_{i}=n_{e}^{a d d}=10^{11} \mathrm{~cm}^{-3}, W_{i}=240 \mathrm{keV}, W^{\text {add }}=2.5 \mathrm{MeV}(\mathrm{b})$; $n_{i}=n_{e}{ }^{a d d}=10^{12} \mathrm{~cm}^{-3}, W_{i}=240 \mathrm{keV}, W^{\text {add }}=2.5 \mathrm{MeV}$ (c)

For a high density $n_{i}=10^{12} \mathrm{~cm}^{-3}$ (Fig. 6,c), the radial spread of the ion beam is so great that its significant part does not reach the region of a uniform magnetic field. The having passed part of the ion beam is inflated in transverse dimensions several times, that makes its use in the sequent cusp of the scheme of induction ion acceleration [5] problematic.

\section{DYNAMICS OF THE ION BEAM COMPENSATED AT THE INPUT OF THE CUSP BY THE AXIAL AND AT ITS OUTPUT BY ANNUAL ELECTRON BEAMS}

As shown in Section 6, it is not possible to realize a charge and current compensated high-current ion beam. It is also unattainable to use an equivalent flow of neutral plasma with a speed corresponding to an energy of $240 \mathrm{keV}$. Nevertheless, assuming that the hypothetical compensation of a high-current ion beam at the entrance to the cusp is feasible, we will consider the dynamics of a high-current ion beam, compensated at the entrance and exit of the cusp, respectively, by a coaxial electron beam and a radial electron beam from the periphery along the entire azimuth to the axis. Above, such electron beams are called main and additional.

The results for low density $n_{i}=10^{10} \mathrm{~cm}^{-3}$ are shown in Fig. 7,a (green particles of the main electron beam are not visible). They coincide with those obtained without the main electron beam (see Fig. 6,a). This is explained, firstly, by the weak divergence of the ion beam for low density and without a compensating electron beam and, secondly, by the blocking of the main electron beam by the space charge field at the bend in the additional electron beam direction.
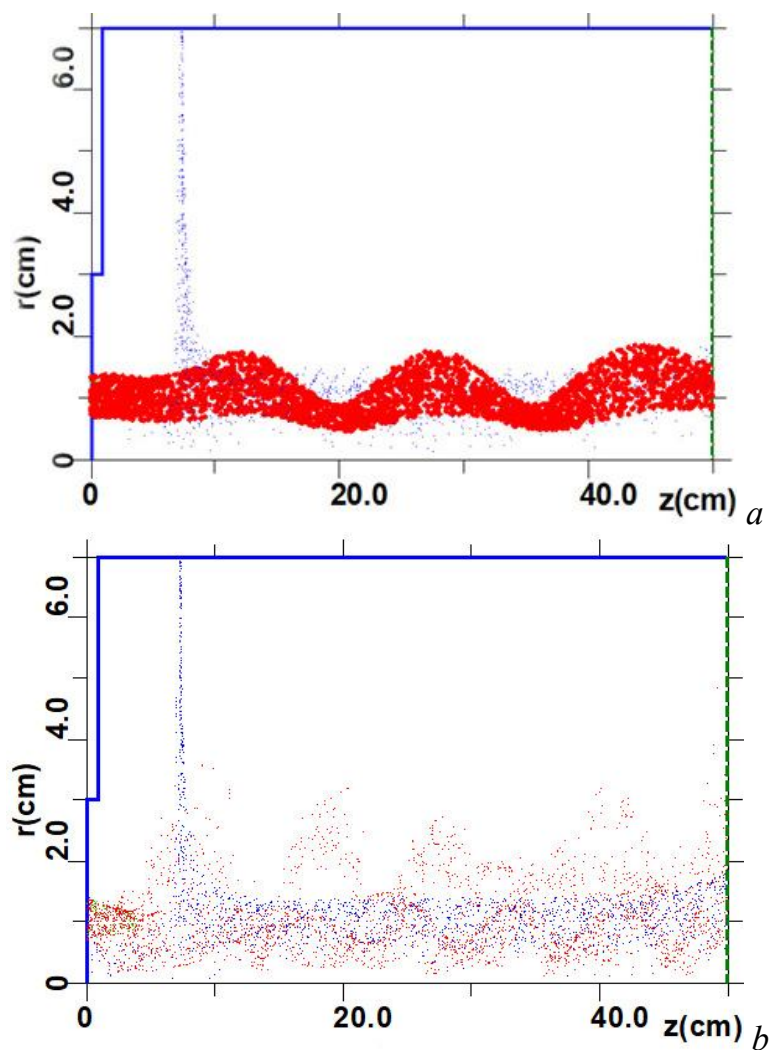

Fig. 7. Arrangement of particles of ion (red), main (green) and additional (blue) electron beams on the $(r, z)$-plane:

$n_{i}=n_{e}^{a d d}=10^{10} \mathrm{~cm}^{-3}, W_{i}=240 \mathrm{keV}, W^{a d d}=2.5 \mathrm{MeV}(\mathrm{a})$; $n_{i}=n_{e}{ }^{a d d}=10^{12} \mathrm{~cm}^{-3}, W_{i}=240 \mathrm{keV}, W^{\text {add }}=2.5 \mathrm{MeV}(\mathrm{b})$

For a high density $n_{i}=10^{12} \mathrm{~cm}^{-3}$ (Fig. 7,b), the main electron beam is blocked (green particles), as in the previous case, and thus does not go along the magnetic field lines into the annular slit of the cusp and does not entrain the ion beam with it. In contrast to the case with 
the absence of the main electron beam (see Fig. 6,c), in its presence (see Fig. 7,b), it compensates for the ion beam before blocking, reducing its divergence and losses at the input. The use of the main and additional electron beams makes it possible to transport a highcurrent ion beam through a cusp and a uniform magnetic field (see Fig. 7,b). However, the ion beam quality deteriorates significantly due to the arising radial oscillations - the transverse size of the ion beam increases, the density inhomogeneity over the cross section arises, and the emittance increases.

\section{CONCLUSIONS}

In $2.5 \mathrm{D}$ numerical simulation of the dynamics of particles of an ion beam in an acute-angled geometry of a magnetic field and a subsequent uniform magnetic field, depending on the density of the beams, the following features were revealed.

In contrast to the single-particle consideration at high densities of the uncompensated ion beam (on the order of $10^{12} \mathrm{~cm}^{-3}$ ), the division of the injected ions into three types loses its meaning due to the Coulomb repulsion of the beam ions. With an increase in the density of beam ions injected as ions of the first type, the number of ions of the second and third types, reflected back or escaping into the annular gap, increases, and the number of ions of the first type passing through the cusp decreases (see Fig. 3,a,b).

In the case of the ion beam compensation by the electron beam to densities of $10^{11} \mathrm{~cm}^{-3}$, the ion beam reaches the middle of the cusp without Coulomb repulsion. Then, after the electron beam leaves the field lines into the annular slit, it completely passes the cusp, moving in a uniform magnetic field with Larmor rotation. At a density of $10^{12} \mathrm{~cm}^{-3}$, the polarization field of the diverged beams is so great that practically the entire ion beam is dragged by the magnetized electron beam into the annular slit. (Fig. 4,c).

The high-current ion beam compensation by the electron beam, radially injected along the entire annular azimuth, is accompanied by the appearance of radially oscillatory motion in the crossed radial electric field of the electron beam space charge and a longitudinal magnetic field, significantly degrading the ion beam quality. Its parameters underperform to those of the initial highcurrent ion beam.

A high-current ion beam, hypothetically compensated by an electron beam to the level of a cold plasma flow, after passing the cusp magnetic field, into the annular slit of which an additional compensating electron beam is radially injected, instead of the locking initial electron beam, turns into a flow of rotating ions and electrons. Such a flow becomes unsuitable for its further use as a compensated high-current ion beam. It is possible to improve the compensation of the high-current ion beam at the exit from the cusp by varying the additional electron beam parameters and the cusp magnetic field geometry.

\section{REFERENCES}

1. K.D. Sinelnikov, N.A. Hizhnyak, N.S. Repalov i dr. Issledovanie dvizheniya chastic $\mathrm{v}$ magnitnyh lovushkah ostrougol'noj geomitrii // Fizika plazmy $i$ problem UTS. Kiev: "Naukova Dumka", 1965, v. 4, s. 388-402 (in Russian).

2. K.D. Sinelnikov, N.A. Hizhnyak, N.S. Repalov i dr. Inzhekciya chastic v zerkal'nuju lovushku s narastajushim polem $\mathrm{v}$ probkah cherez magnitnuju lovushku ostrougol'noj geomitrii // Magnitnye lovushki. Kiev: "AN USSR". 1965, p. 5-18 (in Russian).

3. B.S. Akshanov, N.A. Hizhnyak. Novyi effectivnyi metod razdeleniya izotopov // Technical Physics Letters. Pis'ma v ZhTF. 1991, v. 17, № 6, p. 13-16.

4. N.A. Hizhnyak. Bezopasnaya yadernaya energetika. Nauchno-technicheskie osnovy elektroyadernogo ekologicheski chistogo proizvodstva energii. Kharkov, 2004, p. 107-138 (in Russian).

5. V.I. Karas', E.A. Kornilov, O.V. Manuilenko, O.V. Fedorovskaya. Particle dynamics in the injector of ion linear induction accelerator // Problems of Atomic Science and Technology. Series "Nuclear Physics Investigations”. 2019, № 6, p. 85-89.

6. A. Litvak, S. Agnew, F. Anderegg, B. Cluggish, et al. Archimedes Plasma Mass Filter // 30th EPS Conference on Contr. Fusion and Plasma Phys. St.Petersburg, 2003, v. 27A, O-1.6A.

7. V.I. Karas', V.V. Mukhin, A.M. Naboka. About compensated ion acceleration in magnetoisolated systems // Sov. J. Plasma Phys. 1987, v. 13, № 4, p. 281-283.

8. B.F. Yuferov, A.S. Svichkar, S.V. Sharyy, T.I. Tkacheva, V.O. Ilycheva, V.V. Katrechko, A.I. Shapoval, S.N. Khizhnyak. Redistribution of ion fluxes during simulation experiments on magnetoplasma separation // Problems of Atomic Science and Technology. Series "Physics of Radiation Effect and Radiation Materials Science”. 2013, № 5, p. 100-103.

9. V.P. Tarakanov. User's Manual for Code KARAT // Springfield VA: Berkley Research Associates Inc. 1992, p. 137.

10. Hiroaki Ito, Yasushi Ochiai and Katsumi Masugata. Development of High-current Pulsed Heavy-ionbeam Technology for Applications to Materials Processing // Journal of the Korean Physical Society. 2011, v. 59, № 6, p. 3652-3656.

11. G. Schmidt. Plasma motion in a curved magnetic field // The Phys. of Fluids. 1962, v. 5, № 8, p. 9941002.

12. V.S. Vojtcenya, I.N. Onishchenko, N.A. Khizhnyak, et al. Dvizhenie plasmennogo sgustka v krivilineinom magnitnom pole // Technical. 1967, v. 37, p. 262-267.

Article received 22.06.2021 


\section{ЧИСЛЕННОЕ МОДЕЛИРОВАНИЕ КОМПЕНСАЦИИ СИЛЬНОТОЧНОГО ИОННОГО ПУЧКА ЭЛЕКТРОННЫМ ПУЧКОМ В ОСТРОУГОЛЬНОЙ МАГНИТНОЙ СИСТЕМЕ}

\section{И.Н. Онищенко, О.В. Федоровская}

Представлены результаты 2,5D-численного моделирования динамики частиц сильноточного ионного пучка, движущегося в магнитном поле остроугольной геометрии (каспе), скомпенсированного по заряду и току электронным пучком, инжектированным по радиусу на ось с периферии однородно по азимуту. Выяснено влияние собственных полей пространственного заряда пучков и поляризационных полей на динамику ионов. Показано, что при больших плотностях электронного и ионного пучков электронный пучок, инжектированный в касп вместе с ионным пучком, двигаясь по силовым линиям магнитного поля, увлекает за собой ионный пучок от оси на периферию в область нулевого магнитного поля. На выходе из каспа инжектированный по радиусу на ось электронный пучок дрейфует вдоль оси в однородном магнитном поле, тогда как инжектированный по оси ионный пучок совершает осцилляторное по радиусу движение в скрещенных радиальном электрическом поле пространственного заряда электронного пучка и продольном магнитном поле.

\section{ЧИСЕЛЬНЕ МОДЕЛЮВАННЯ КОМПЕНСАЦІЇ СИЛЬНОСТРУМОВОГО ІОННОГО ПУЧКА ЕЛЕКТРОННИМ ПУЧКОМ У ГОСТРОКУТНІЙ МАГНІТНІЙ СИСТЕМІ}

\section{І.М. Оніменко, О.В. Федорівська}

Представлено результати 2,5D-чисельного моделювання динаміки частинок потужнострумового іонного пучка, що рухається в магнітному полі гострокутної геометрії (каспі), скомпенсованого за зарядом і струмом електронним пучком, інжектованим за радіусом на вісь 3 периферії однорідно по азимуту. З'ясовано вплив поляризаційних полів на динаміку. Показано, що при великій щільності електронного та іонного пучків електронний пучок, інжектований в касп разом з іонним пучком, рухаючись за силовими лініями магнітного поля, захоплює за собою від осі іонний пучок на периферію в область нульового магнітного поля. На виході 3 каспу інжектований за радіусом на вісь електронний пучок дрейфує уздовж осі в однорідному магнітному полі, тоді як іонний пучок здійснює осциляторний за радіусом рух у схрещених електричному полі просторового заряду електронного пучка і зовнішньому магнітному полі. 